\title{
Kerpel-Fronius Balázs' \\ ÁtÁNyI CsILLAGPONT, EGY TANODA TAPASZTALATAI A Vírus ALATT
}

\author{
DOI 10.35402/kek.2020.4.4
}

\begin{abstract}
Absztrakt
2020 márciusában a Covid-19 vírus megjelenését követően meghozott intézkedések egy eddig még nem tapasztalt nehézség elé állították az egész magyar oktatási rendszert. Már ekkor sejthető volt, hogy a „digitális oktatásra” való átállás hatalmas feladatot fog jelenteni mind a pedagógusok, mind a tanulók számára. Közvetlen környezetében mindenki láthatott, hallhatott példákat, hogy milyen megoldások születtek ebben a speciális helyzetben, szóltak a hírek ingyenessé váló szoftverekről, és ezekkel a programokkal rekordidő alatt ismerkedni próbáló tanárokról, online testnevelés órát tartó pedagógusokról. Arról azonban kevesebbet tudunk, csak sejtéseink lehetnek, hogy mi történt ez időszak alatt azokon a településeken, azokban az iskolában, ahol a digitális átálláshoz a minimális tárgyi feltételek sem adottak. Egy ilyen község például Átány, ahol a SZIA (Szociális Innováció Alapítvány) Csillagpontja működik. Ennek a csapatnak a karantén alatti munkáját, az általuk alapított tanoda nehézségeit, a felmerülő problémákat és az ezekre adott válaszokat szeretném bemutatni.
\end{abstract}

\footnotetext{
Abstract

In March 2020, measures taken following the appearance of the Covid-19 virus presented the Hungarian educational system with unprecedented difficulties. Even then, it was foreseeable that the transition to "digital education” would be a huge task for teachers and students alike. In their immediate environment, everyone could observe examples of what kind of solutions were found in this special situation. There were news of softwares and applications becoming free, and of teachers trying to learn about these in record time. Another example was an educator holding an online physical education class. However, we can only have a guess as to what happened during this period in those

1 SZTE BTK II. éves szociológus hallgató, a vírushelyzet alatt egy hétig Átányban, egy hétig Balatonszemesen követte résztvevő megfigyelőként a szociális munkások mindennapjait.
}

settlements, in those schools where the bare minimum of material conditions for a digital transition were not in place. One such village is Átány, where the Csillagpont of SZIA (Social Innovation Foundation) works. I would like to present the work of this team, the arising difficulties in their classroom environment, and their answers to these problems.

\section{Átányról és a Csillagpontról}

Átány egy 1490 fös² község, mintegy másfél órányi autóútra Budapesttől, és tízpercnyire Hevestől. A település hivatalosan három szegregátumra van osztva, ${ }^{3}$ a SZIA alapítványának munkatársai a hármas számúban dolgoznak. Nem beszélhetünk azonban klasszikus szegregátumról, hiszen ezen a területen - mint ahogy az egész községben is - akár egy utcában is élnek egymás mellett jobb módú, illetve súlyosan hátrányos helyzetű családok. A SZIA Alapítvány Átányi Csillagpont projektje elsősorban nem a gyerekeket célozza (a családoknak nyújtana segítséget szociális ügyekben, illetve gyakran valamiféle moderátori szerepet vállalva a község roma és nem roma tagjai közt), de délutáni tanodát is müködtetnek, amibe egyre több, leginkább roma gyereket sikerült bevonni az évek során. A kialakult helyzetben, a COVID-19 vírusra tekintettel azonban az itt dolgozó szociális munkások eddigi tevékenységei nagyrészt ellehetetlenültek, például nem tudták folytatni a családlátogatásokat sem, így a felszabadult idejüket megpróbálták teljes mértékben a gyerekek tanulmányai segítésének szentelni.

\section{A tanoda „békeidőben”}

A tanodának egy barátságos kerttel rendelkező, átalakított, helyi viszonylatban meglehetősen

2 2015. jan. 1.-i adat.

3 A szegregátumokat a KSH osztotta fel saját módszertan alapján a 2010-es évek elején, a SZIA szociális munkásai ezek alapján kezdték el a munkájukat 2018-ban. 
jó állapotban lévő családi ház ad helyet, amit az átányiak csak Csillagpontként emlegetnek. A házban két szoba lett tanításhoz, játékhoz kialakítva, illetve jó idő esetén a kertben is tarthatóak foglalkozások. Ezeket vírushelyzet előtt hetente körülbelül 40 gyerek látogatta, a felső tagozatosok kettőtől fél négyig, illetve az iskolaotthonból érkező alsó tagozatos gyerekek fél négytől ötig vagy hatig maradhattak. Mivel az alapítvány három szociális munkásból áll, és egy helyi pedagógus segítségét veszik igénybe, ezért mindenki egyéni oktatására sajnos nincs lehetőség. Kisebb csoportokban dolgoznak, osztályok szerint szétválogatva. A szociális munkások viszonyukat a helyi tanári karral (az őket segítő pedagógusokat nem számítva) ambivalensnek írják le, elmondásuk szerint sokszor érzik úgy, hogy az iskola egyes pedagógusai felől nem mindig a támogató szándék az uralkodó szemlélet irányukba, és korántsem mindig megfelelő a kommunikáció az iskola illetve a Csillagpont munkatársai között.

$\mathrm{Az}$ egyik legnagyobb nehézség a tanoda kapcsán, hogy a gyerekek sokszor nem értik az iskolában tanultakat, a délutáni foglalkozásokon pedig gyakran csak az aktuális házi feladat elvégzésére van lehetőség. Tanítás után sokszor fáradt, kiégett gyerekek érkeznek a foglalkozásokra, ilyen körülmények között pedig felzárkóztatásra nincs, nem marad elegendő idő, energia.

\section{Tanodából „iskola”}

Így érkezett el a tanoda március 13.-hoz (péntek). A magyar kormány ekkor jelentette be, hogy a következő hétfőtől vírushelyzetre való tekintettel átalakul az iskolai élet, a diákok nem látogathatják az intézményeket. Az alapítvány munkatársait már aznap több szülő megkereste, érdeklődve arról, hogyan fog folytatódni a munka. A szülők kétségbeesése érthető volt, hiszen az átányi családok jelentős része nem rendelkezik internettel, illetve a digitális oktatáshoz megfelelő okoseszközökkel, így ezek a már egyéként is hátrányos helyzetű gyerekek teljesen kilátástalan szituációba kerültek volna a Csillagpont bezárása esetén. A kialakult állapotra a tanoda egészen gyorsan reagált, pár nap leforgása alatt gyakorlatilag egy „mini iskolát” hozva létre az alapítvány épületében.

De hogyan is valósult ez meg? A leállás utáni első napokban csak néhány gyerek látogatta rendszeresen tovább a tanodát, majd a következőkben egyre többen és többen jöttek volna. Egy-két hét elteltével azt figyelték meg, hogy a gyerekek már egymással versenyeznek, hogy ki ér előbb a Csillagpont kapujához, hiszen eddigre tudták, hogy csak az első érkezőt, érkezőket tudják fogadni egyből a szigorú biztonsági előírások miatt, így az ekkor kimaradóknak később kellett visszajönniük. Ezeken az időpontokon azonban gyakran már nem jelentek meg. A szociális munkások erre reflektálva döntöttek úgy, hogy a délutáni tanodát átalakítják, és a diákokat egyesével beosztva reggeltől várják, hogy minél többükre jusson valamennyi idő. Az oktatás minden nap általában kilenc órától, délután ötig, hatig tartott, a biztonsági előírások betartása mellett.

\section{A foglalkozások}

Gyakran problémát okoztak a vírus miatt meghozott komolyabb szabályok is, például nehézségekbe ütközött betartatni a szigorúan kötött időpontra érkezést olyan gyerekekkel, akik alapvetően nem rendelkeznek megszokott napirenddel. Az átányi fiatalok ráadásul addig általában tanítás után, együtt érkeztek a délutáni foglalkozásokra, közösen játszva, egymást csábítva a Csillagpontba, ám ebben az időszakban csak az egyéni motiváción, illetve a szülők szigorán múlt a tanoda látogatása. Ez azért nem elhanyagolható körülmény, mert jelen helyzetben nem találkoztak pedagógusaikkal sem, akik bíztatják őket erre, így olyan szülőkre hárult a motiválás feladata, akik maguk is gyakran legfeljebb nyolc osztállyal rendelkeznek és olyan családokra, ahol a tanulásnak még nem alakult ki kultúrája.

Nehézséget okozott továbbá, hogy mivel a tanoda munkatársai a lehető legtöbb gyereknek szerettek volna segítséget nyújtani, így egy-egy diákkal szünet nélkül foglalkoztak, ráadásul tömbösítve tudtak csak haladni, ami kimerítette mind a diákokat, mind az alapítvány munkatársait. Megfigyelhető volt, hogy ennek következményeként még az olyan gyerekeknek is csökkent a motivációja, elmaradoztak (különösen az utolsó hetekben kellett sokat bíztatni őket), akik addig szorgalmasan látogatták a Csillapontos foglakozásokat. Ezt érzékelve, hogy a terhelést csökkentsék, a tanulás ne legyen ennyire megterhelö, egyre többször lettek beiktatva játékos szünetek, amivel a légkör is még szabadabbá válhatott. Minden igyekezet ellenére azonban, az alapítvány munkatársainak számításai szerint a megszokottan tanodába járó gyerekek mintegy húsz százalékát teljesen elvesztették a leállás alatt. 
A megmaradtakkal kapcsolatban azonban általános tapasztalat, hogy nagyrészt szívesen jöttek a foglalkozásokra, még azok is, akiknek az iskolalátogatásával korábban komoly problémák adódtak. Ennek egyik oka lehet, hogy a kiscsoportos/egyéni foglalkozásokon - a formális iskolai oktatással szemben - végre több idő, elég figyelem jutott rájuk, az oktatás pedig jóval kötetlenebb volt. Ráadásul, mivel az iskolai házi feladatok határideje kitolódott, így lehetőség nyílt végre a felzárkóztatásra is, végre több sikerélményhez jutottak egy-egy feladat tényleges megértésekor. Az ilyen felzárkóztató, „saját tempójú” órák után érzékelhetően jobban lehetett haladni az aktuális tananyaggal is, érezhető volt, mikor a diákok valós tudásra tettek szert. Könnyen észrevehető, hogy mennyire tudnak lelkesedni, érdeklődni bizonyos témák iránt, hogy minden egyes apró sikerélmény, feladatmegoldás nagy örömmel tölti el őket, ezeket a pillanatokat lehet, lehetett később tanáraiknak motivációként használni.

\section{A pedagógusok szerepe}

Ezen a ponton kell megemlíteni a Csillagpontot segítő tanítónőt is. A fiatalokkal való beszélgetések alapján úgy tünik, hogy leginkább első osztályos tanítónőikhez kötődnek érzelmileg, később már egyre több konfliktus alakul ki tanáraikkal. Ezek a pedagógusok hihetetlen szeretettel tudnak feléjük fordulni, hatalmas empátiával kezelik és követik az olyan speciális helyzeteket, amik hatással lehetnek a diákjaik viselkedésére, akár börtönbe került szülő vagy testvér esetén, akár az intézetből nevelőszülőkhöz került gyerekek ingadozásait. A leállás alatt ez a fajta odafordulás talán fontosabb volt, mint eddig valaha, hiszen ezen tanítónők pontosan tudták, hogy melyik diáknak, milyen jellegű felzárkóztatásra van szüksége, és ami talán még fontosabb: mivel motiválhatók. Esetlegesen ennek a szorosabb kapcsolatnak is köszönhető, hogy az alsós tanulók kisebb számmal morzsolódtak le az online oktatás alatt, mint idősebb társaik.

A motiváció pedig kulcs. A tanodát látogató fiatalokkal beszélgetve nyilvánvalóvá válik: igen ritka, hogy bármilyen sikerélményük legyen a közoktatásban, a feladatok megoldása közben erős önbizalomhiánnyal és bizonytalansággal küzdenek. A szavaikból kiderül, hogy az iskolát nem szívesen látogatják, nemigen kerülnek elő beszámolóikból pozitív érzések, élmények. Sokuknál magatartásbeli, szorgalmi problémák is megfigyelhetőek, így fontos volt, hogy a tanodával kapcsolatban minél kedvezőbb benyomásaik, érzéseik legyenek, hiszen ennek látogatása önkéntes volt.

A szorgalom ingadozását, a papíron kinyomtatott házi feladatok kapcsán lehetett a legjobban megfigyelni. Mivel minden igyekezet ellenére sajnos nem jutott minden családnak, gyereknek segítség, így a "Csillagpontosok” a kimaradó diákoknak is próbáltak valamiféle kapaszkodót kínálni: az iskolában feladott összes lecke kinyomtatva átvehető volt az irodájukban minden nap délután négy és öt óra között. Ezeket otthoni kitöltés esetén másnap az alapítványban dolgozók „fotózták be” és küldték el az iskola pedagógusainak. Gyakori tapasztalat volt azonban, hogy a kinyomtatott lapokat akár többen is hazavitték, ám a másnapi bemutatásra ezek már nem jutottak vissza a Csillagpontba. Nyilván nem tudhatjuk, hogy mi történt az otthoni leckeírás során, ha volt ilyen - de azt láthatjuk, hogy a fiataloknak messze nem csak a feladatmegoldás nehézségeivel kellett szembenézniük, ha az otthontanulást választották, vagy nem jutott nekik hely a tanodában.

\section{A fiatalok nehézségei}

Először is le kellett győzniük a kísértést, hogy az otthoni munka helyett inkább kortársaikkal focizzanak, vetőzzenek ${ }^{4}$ vagy kilencesezzenek. ${ }^{5}$ A szabadidő élvezetesebb eltöltésének kísértése után kiderült, hogy az átányi háztartások túlnyomó részében a legelemibb kritériumok sem adottak az otthontanuláshoz: sokaknál az áram sincs bevezetve, nagy részük túlzsúfolt, és mint már korábban említettem, nem rendelkeznek internettel, számítógéppel, laptoppal, sőt gyakran íróasztallal sem. A másik felmerülő hatalmas probléma a szülők érdemi segítségének hiánya. Nem volt ritka az olyan eset, hogy nyolcosztályos bizonyítvánnyal sem rendelkező szülő (az átányi szülők legnagyobb részére igaz, hogy maguk sem végezték el az általános iskolát) próbált otthon 3-5 gyerekkel tanulni, ami nyilvánvalóan messze nem ideális állapot. Sajnos gyakori visszajelzés volt, hogy ebben az igyekezetben néha maga a tanári kar sem nyújtott megfelelő segítséget a családoknak. Az egyik ilyen esetben például a

4 Az átányi (roma) gyerekek és felnőttek egyik kedvenc játéka, tulajdonképpen aprópénzzel való célba dobás, egy földön meghúzott vonalra.

5 Kártyajáték, amit a fiatalabbak általában tét nélkül, a felnőttek gyakran nagyobb tétekkel játszanak. 
szülő maga töltötte fel a megoldott feladatsorokat az iskola erre a célra létrehozott nyilvános falára, de állítása szerint visszajelzést csak egy-két tanár adott, hogy jó-e a megoldásuk. A rossz válaszoknál nem kaptak konkrét indoklást, hogy mi a hiba, csak negatív kommenteket egy nyilvános fórumon. Képzelhetjük, hogy egy-egy esetleges feladatlap-leadás mennyi energiájába kerül egy ilyen családnak és hogy az ilyen kritikák - pláne nyilvános Facebookfalakon - mennyit ártottak nemcsak a gyerekek, de a felnőttek önbizalmának is. Ezek a tanulók később sokszor inkább megpróbáltak mégis Csillagpontos időponthoz jutni, ám erre csak felszabaduló időpontok esetén volt lehetőségük.

\section{Oktatás a tanodában}

Mint látjuk tehát, a tanárok felelőssége természetesen mindenhol hatalmas a digitális oktatás során, mégis talán hatványozottan igaz ez egy olyan helyzetben, mint amilyenbe az átányi és a hozzájuk hasonló helyzetű fiatalok kerültek. Az ő lelkesedésüket fenntartani több hónapig egy olyan közegben, amelyben a tanulásnak még nincs tradíciója és értéke, ez valóban embert próbáló feladat. Voltak pedagógusok, akik kizárólag másolást igénylö feladatokat adtak fel „befotózandó” leckének, de ezekkel kapcsolatban hamar észrevehető volt, hogy nyilvánvalóan nem érik el a kívánt eredményt. A diákok olykor teljesen mechanikusan másoltak le akár tíz oldalt is, de az anyaggal kapcsolatos legelemibb kérdésekre sem tudtak válaszolni, sőt előfordult olyan eset is, mikor a szöveghez kapcsolódó tantárgyat sem sikerült megnevezniük. Ezek a feladatok ráadásul plusz terhet tettek a szociális munkások nyakába, hiszen a másolással rengeteg idő veszett el, majd ugyanezt az anyagot kellett megértetni a gyerekekkel az automatikus leckeírás után.

Nagy szolgálatot tettek ugyanakkor az Okosdoboz $^{6}$ és a Tankocka ${ }^{7}$ internetes oldalainak feladatai, amelyek játékos módon segítették a diákokat a sikerélmények megszerzésében. A koronavírus egyértelműen pozitív hozadéka volt ez, hiszen

6 Egy digitális feladatgyüjtemény tantárgy/évfolyam bontásban. Találhatóak a weboldalon játékok, fejlesztőfeladatok is. http://www.okosdoboz.hu/ (letöltés: 2020.10.07).

7 Ezen oldalakon szintén feladatsorok találhatók, illetve itt pedagógusok is tudnak saját feladatlapokat létrehozni. http://kockalapok.hu/, https://learningapps. org/ (letöltés:2020.10.07.) ezekkel az online leckékkel a tanoda oktatói is némi pihenőhöz jutottak. Meg kell azonban említeni, hogy az iskolával való kommunikáció fö színterének szánt Kréta $^{8}$ felület okostelefonokkal nem volt egészen kompatibilis, nem minden funkciója volt elérhetö, így aki - esetleg rendelkezett ilyennel és ezzel próbálta megoldani ezt a kihívást, annak sem sikerülhetett teljesen.

A folyamatos munka során tapasztalható volt a fejlődés is egyes diákoknál. Amint nem csak kudarccal találkoztak, látni lehetett, hogyan lesznek egyre magabiztosabbak, mikor valóban megértettek valamit, hogyan lesznek büszkék a jó válaszaikra. Ezekbe a sikerélményekbe kellett kapaszkodniuk a tanodában dolgozóknak, illetve a pedagógusoknak is, mert ezen túlmenően nincs sok motiváció a tanulásra, és fóleg érvényes lehet ez az ilyen községek, falvak diákjaira. A helyi fiatalokkal beszélgetve hamar kiderül, hogyan látják a lehetőségeiket a jövőben. Nem ritka az olyan idősebb (15-16 éves) gyerekek véleménye, hogy csak a nyolc általánost kell majd elvégezniük, hiszen utána már el tudnak helyezkedni a községben is jelenlévő - a helyi polgármester által nagyon is támogatott - közmunkaprogramban. Viszonylag pontosan érzékelik a saját helyzetüket, jövőbeni lehetőségeiket egy olyan községben, ahonnan eljutni Egerbe a Vendéglátó és Idegenforgalmi Technikumba már komoly kitörésnek számít, eljutni a Miskolci Rendvédelmi Technikum padjaiba pedig egy távoli álomnak. Hogy ez miért van így, az már messze túlmutat a digitális oktatás problémakörén.

\section{A vírus után}

A szociális munkások, segítők, illetve az iskolákban dolgozók megfeszített munkájának eredménye természetesen az év végi bizonyítványokon is megmutatkozott. A tanodát rendszeresen látogató diákok sikeres félévet teljesítettek, sőt, volt, hogy félévi bukás után, akár két jegyet is tudtak javítani. Ezek a tanulók a pozitív visszajelzések mellett, jutalmul öt napot tölthettek el Balatonszemesen a SZIA Alapítvány jóvoltából. Ebben az öt napban rengeteg plusz élményt tudtak szerezni, azonban a munka is folytatódott, hiszen a foglalkozások itt sem szüntek meg, alkalom nyílt felzárkóztatásra és korai fejlesztéses órák tartására is, még felszabadultabb hangulatban és lazább környezetben.

8 https://tudasbazis.ekreta.hu/ (Letöltés: 2020.10.07) 
Nem szabad megfeledkeznünk azonban azokról a diákokról sem, akik minden igyekezet ellenére a leállás alatt szinte teljesen kiestek a magyar közoktatásból, hiszen ők az eddigi lemaradásuk mellé most még három hónapot gyűjtöttek. Az alapítvány munkatársai a tanév végével, a karantén feloldása után keresték fel ezeket a fiatalokat és a nyáron velük próbáltak leginkább foglalkozni, felkészíteni őket a pótvizsgákra, felzárkóztatni kortársaikhoz. A pedagógusoknak pedig szeptembertől kell megpróbálni ezt a hátrányt eltüntetni úgy, hogy közben az éves tananyagot is elsajátítsák a diákok. Ez korántsem tűnik egyszerű feladatnak - a koronavírus átányi hozadéka azonban, hogy kialakultak és már rendelkezésre állnak olyan (Facebook) csoportok, platformok az iskola pedagógusai, a Csillagpont szociális munkásai és a szülők között, amik végre előremozdíthatják az eddig nagyrészt negatívként értékelt kommunikációt és ez alapja lehet akár egy egymással kooperáló rendszer megteremtésének a jövőben.

\section{Összegzés}

Kijelenthetjük, hogy a koronavírus járvány alatt bevezetett digitális oktatásra a magyar közoktatás jelentős része nem volt felkészülve és az államtól ehhez megfelelő segítséget nem kapott. Megállapítható továbbá, hogy ezek a problémák az átányi, és ahhoz hasonló vagy akár rosszabb életkörülmények között élő, az oktatásban eleve hátrányban, lemaradásban lévő fiatalokat érintették leginkább. Az itt kialakult helyzet tehát valószínűsíthetően egyáltalán nem egyedi az országban, sőt biztosan vannak települések ahol ennél is kevesebb lehetőséggel rendelkeztek a fiatalok, ilyen jellegü segítség híján.

A Csillagpont tanodájának példája jól mutatja, hogy a vírus alatt a különböző szociális munkások, civil szervezetek, hogyan tudták az eddigieknél is hatékonyabban segíteni e gyerekek tanulmányait egy olyan helyzetben, mikor a közoktatás képtelen volt megfelelő lehetőségeket biztosítani számukra. Ne feledjük, az ilyen civilek, önkéntesek munkája nélkül ezek a fiatalok nem csak az „árnyékoktatás” lehetőségétől, hanem a közoktatásban való teljes értékủ részvétel lehetőségétől lennének megfosztva.

9 Ezek a tanodák a kevésbé tehetősek számára értelmezhetőek valamiféle „árnyékoktatásként”. 